of the former seem also to be perforate. The new genus is distinguished from Syringocnema by the presence of irregular septa, and so can be compared with Pyonoidocyathus and Spirocyathus of Taylor; its mode of growth seems to be essentially the same as that of the Archæocyathinæ. These specimens are described and figured in "Notes on Fossils from Limestone of Steeprock Lake, Ontario" (Appendix to Memoir No. 28, Geol. Survey Canada, 1912).

\title{
VIII.-Brief Notices.
}

1. Metronic Stone from Kansas.-A second meteoric stone has been found in Scott County, Kansas, and this forms the subject of a paper by Dr. George P. Merrill (Proc. U.S. National Museum, No. 1905, vol. xlii, pp. 295-6, with pl. xxxix, 1912). It is a wedgeshaped fragment weighing 1,900 grams, and it has a fracture so recent that it is scarcely coated by a fused crust. The specimen, which is to be known as the Scott City stone, is chondritic, and the microscopic chondrules are of the usual olivine-pyroxene type, but nothing. that could be with certainty identified as a felspar was observed.

2. Waverlyan Period of Tennessee.-The formations that are grouped under this period are in ascending order the Chattanooga, Kinderhookian, and Osagian, and they belong to the lower part of the sub-Carboniferous or Mississippian strata. The palæontological and stratigraphical relations of the formations are discussed by Mr. Ray S. Bassler (Proc. U.S. Nat. Mus., xli, p. 209, 1911).

3. VARISCITE FRoM Uta Mr. W. T. Schaller describes specimens of well-crystallized variscite from near Lucin in Utah. 'The mineral is found in a hard brecciated cherty or chalcedonic quartz-rock, which contains inclusions of nodules and streaks of limestone. It is a hydrous aluminium phosphate with traces of vanadium, chromium, and iron oxides, and it occurs in balls, nodules, and irregular masses in the chert. In colour the variscite ranges from a very pale green to a bright grass green. Gems are cut from it for pendants, brooches, pins, etc., but the stones are not adapted for rough wear.

4. Mining in Sodth Australia.-A review of mining operations in South Australia during the half-year ended December 31, 1911, has been compiled by Mr. Lionel C. E. Gee, Chief Registrar of the Department of Mines. The mining operations, in order of importance, relate to copper, gold, salt, silver-lead, and other minerals, including phosphate, gypsum, pyrites, hæmatite, wolfram, and uranium-ore.

\section{MISCEIIANFOUS.}

\section{The Great Flood at Norwich.}

Our readers will have learnt from the newspapers of the great calamity which has befallen the city of Norwich and large areas of Norfolk.

In November, 1878, disastrous floods occurred at Norwich after sixteen continuously rainy days, with some snow, when 4.50 inches 